\title{
Operational Risk Management in Financial Institutions: An Overview
}

\author{
Abdullah Aloqab (Corresponding author) \\ School of Economics and Trade, Hunan University, Hunan, 410082, China \\ E-mail: abdullahaloqab02@gmail.com
}

Farouk Alobaidi

School of Economics and Trade, Hunan University, Hunan, 410082, China

Bassam Raweh

School of Economics and Trade, Hunan University, Hunan, 410082, China

Received: January 25, 2018 Accepted: February 9, 2018

doi:10.5296/ber.v8i2.12681 URL: https://doi.org/10.5296/ber.v8i2.12681

\begin{abstract}
After the 2008 financial crisis, many attributed the crisis due to the inability of financial risks to manage operational risks. The period during and after 2008 was critical in providing insight on how vital operational risk management is essential to financial institutions and how best these risks can be managed. The study begins with an overview of the concept of risk and BASEL I, II and III and how they apply to financial institutions. Further, the paper discusses the growing need for operational risk management in the context of financial institutions taking into considerations various models and approaches used in the management of financial risks. Moreover, several pieces of literature discussed operational risks in the financial institutions. The paper also looks at the various methods of operational risk identification and management before concluding that for better management of operational risks in banks, there is the need to comply with both the national and international regulations and procedures.
\end{abstract}

Keywords: Risk management, Operational risk management, Basel committee, Bank, Financial institutions 


\section{Introduction}

The 2008 financial crisis led to the discussion of different aspects as the reason for the failure of most banks and financial institutions, and this is the reason why there is extensive literature on operational risks in financial institutions. Sabato (2010) contends that a strong belief that banks were too vast to fail is one of the reasons that led to the failure of financial institutions in 2008. Another issue was the lack of clearly defined strategy that could be used for risk allocation. Hess (2011) observed that one of the major causes is the failure of financial institutions in 2008 and even now is the lack of proper operational risk management strategy in particular. Schwartz-Gârliste (2013) adds that the relevance of the issue of operational risk management has grown so much to attract the attention of the global banking sector. Because of this, constant and advance research on operational risk in financial institutions has been identified as one of the ways that can be used to ensure coherence and efficient financial management, which in future can be used to avoid the challenges witnessed during the great financial crisis.

This paper begins with an overview of the risk and BASEL I, II and III and how they apply to financial institutions. Further, discusses the growing need for OR management in the context of financial institutions taking into considerations various models and approaches used in the management of financial risks.

\section{Concept of Risk in Financial Institutions}

Bank risks are multifaceted and not as straight as many thinks. According to Hamberg (2000), in the ancient Greek, the risk was mostly used in uncertain situations to mean to dare. Kaplan and Garrick (2006) noted that since risks are unavoidable, it is crucial for individuals to confront when presented with risk situations with unpredictable outcomes. It should be noted that early research show there is a big difference between uncertainty and risk. Specifically, Hamberg (2002) contends that risks are situations where the probability of the outcome is predictable while uncertain situations; on the other hand, the expectation is unknown. Further, Kaplan and Garrick (2006) observe that risk involve uncertainty and often involve some damage or loss. Additionally, Cornia et al. (2016) contend that what risks either internal or external, may not be the case in future.

Risk can also mean a kind of unplanned events whose financial consequences leads to reduced earnings or loss, Vasavada et al. (2005). Any activity or operation that results in loss or gives profits may be referred as a risky proposition because of unpredictability or uncertainty of the trading activity. In simpler words, the risk is defined as uncertainty to an outcome.Even though the term uncertainty and risk are commonly used together and synonymously, there exists a difference between these two terms Sharan (2009). In business, uncertainty refers to a case where a decision-maker is aware and knows the outcomes expected from a particular act. Naturally, risks are the quantifiable uncertainties.

Kaplan and Garrick (2006) note that all the investment risks should be measured and weighed correctly. Genegoda \& Evans (2014) add that knowledge regarding the environment which the bank operates are important in risk reduction. Assessing the risk in banks by identifying 
their likelihood and the possible financial impact can help in the classification of major risks in banks and save the banks huge resources. However, the implication of risk depends on the risk culture and appetite of the banks.

\section{Basel Committee in Banking}

The committee was started in 1974, by all the governors of central banks from the G-10 countries. The committee aimed to provide supervisory practices and regulations in the aftermath of what was a serious disturbance of the global financial market and currency. The countries that produced the committee members were Canada, Belgium, Germany, France, UK, USA, Sweden, Spain, Japan, and Luxemburg. The Bank provides the secretariat of the committee for International Settlement, where all committee sittings take place.

At the start of the 80s, the Basel Committee developed its very first framework for financial supervisory that came to be called BASEL I. It was majorly on capital adequacy and capital risk. The committee recommended all financial institutions to set aside 8 percent of all the capital spent on loans using a single matrix system. In essence, it meant that when financial institution sanctions a loan of one hundred million, eight million should be set aside as own funds for the institution. According to Bitar et al. (2017), The paper provides substantial evidence that proves something that adherence of Basel Core principles (BCPs) has a strong positive influence on the Z-score of conventional banks, although less evident on the Z-score of Islamic banks. Using a sample of banks operating in 19 developing countries, the results appear to be driven by capital ratios, a part of Z-score for the two types of banks. Even though smaller on Islamic banks, individual chapters of BCPs also suggest a positive effect on the firm and steady nature of conventional banks. The findings support the useful role of BCP standards in improving bank strength. However, the BASEL I faced a lot of criticism on the ground that the system used was biased towards the financial institutions and system of the G-10 countries and was seen as narrow and incapable of guaranteeing the stability of global financial institutions. Thus leading to the development of BASEL II.

Based on Basel Committee on Banking Supervision (BCBS) (2004), BASEL II depends on three reinforcement pillars in protecting financial institutions from operational risks and bring transparency in the banking sector. They include the minimum capital requirement, supervisory review process, and enhanced disclosure, Di Renzo (2007). It was BASEL II that led to the explicit treatment of operational risk in financial institutions resulting in a capital measure of operational risk. According to Ibrahimovic and Franke (2017). The purpose of this paper is to examine the relationship between the availability of the information system and the loss of operational risks and the capital requirements. According to the first pillar of Basel II agreement, the interruption of information technology in the banking sector leads to increased capital requirements, thus creating additional regulatory costs, in addition to direct and indirect costs of disruption.

BASEL II is an established standard that was initially issued by the BCBS (2004). It was intended to facilitate the rules and procedures of managing operational risks in financial institutions. BASEL II requires the consideration of proper measures by financial institutions to have a culture of high-risk management across all financial institutions. Further, it reflects 
on the improvements of ORM practices that can assist banks and other financial institutions in planning and foresee the future. Although BASEL II has been widely accepted and adopted as part of the bank practices, there are several negative opinions regarding kits applications in risk management.

Because of the negativity associated with BASEL II, in 2010, BCBS issued the third accord which was a new and a much-improved standard for the management of banks liquidity risks. BASEL III aimed at intensifying the existence of capital requirements in banks to enhance the overall strength of the global banking system. Early research on the implementation of Basel III suggests good progress. BASEL III has proved useful in providing the necessary directions for the improvement of the overall financial stability of the institutions. The primary need for Basel III was to develop a new and efficient internal control system that could be applied during the period of financial distress. However, since Basel III was an improvement of BASEL II, it still faces many shortcomings. As an example, BASEL III framework only manages foreseeable risks. Also, the implementation of Basel III has raised several discussions because it applications changed many apparatuses in the banking system globally.

\subsection{Operational Risk}

According to the BCBS (2004), operational risks are the risks of the loss coming from a failed or an inadequate internal process, system, people or sometimes external events. The definition comprises of legal risks and excludes reputation and strategic risks. The explanation provided by BCBS (2004) is a breakdown of four causes of operational risks in a financial institution: processes, people, and system and external events. Cummins et al. (2006) write that one of the most significant and perfect examples of operational risk in a financial institution was the $\$ 1.3$ billion loss that Barings Bank incurred. The loss was caused by a single individual, Nick Leeson, who assumed an unauthorized speculative position and meant the bank to accumulate losses until it was declared bankrupt in 1975 continually.

Operational risk is the vast discipline focusing on the risks increasing from the people, systems, and processes through which a firm operates. It can also include other Categories of risk, such as legal risk, fraud, physical or environmental risks. Revell (1979). It arises from a wide range of activities like acts of frauds, errors, negligence, violations, events of technological failures, process deficiencies, systems flaws, actions of terrorists and vandalism, natural disasters, like floods, earthquakes, etc, Hussain et al. (2014).

Nystrom (2002) contends that operational risks are not unique for financial institutions and nowadays, there is an increasing global need to manage operational risks. Financial institutions across the globe are developing risk management systems, and most of them are trying to achieve efficiency in risk management and reallocation. Nystrom notes that the primary component of ORM in a financial institution is to identify the risk that the institution is likely to face in its operations. One way of mitigating these risks is by setting aside capital for unforeseen and potential losses

According to Padganech (2010), Operational risks are as old as financial institutions. 
However, the emergence of globalization and deregulation of financial institutions together with technological advancements and the evolved scenes of the global financial views and made it critical for financial institutions to pay more attention to operational risks. Researcher contends that operational risks are the outcome of the people in charge, the financial system in place, the financial process applied or other external events that can affect a financial institution. The type of risks originating from the people in charge can stem from management and human resource failure. When examining how the process operates, a breakdown can derive from the violation of the stable operation or failure to strictly follow the procedures. System risk can include technical failures and other internal problems. Lastly, external events can include vandalism, theft and market failures.

The Bank of Japan has a slightly different definition of operational risk as that one provided by BCBS, Chernobai et al. (2008). According to the Bank of Japan, operational risk does not necessarily inflict a direct loss on financial institutions. Instead, an institution can suffer through a decline of reputation. Also, it is possible for the third party to incur losses. Because of this, identification of operational risk in banks is not an easy task to extrapolate. The bank of Japan classifies operational risk into two broad categories: primary and minor threats. The latter can be due to clerical errors or minor computer glitches while the former can be due to unauthorized trading as it was with the Barings Bank as discussed by Cummins et al. (2006).

In addition to the BASEL II definition, the Islamic Bank includes Sharia noncompliance and failure by the financial institution to meet its fiduciary obligations as part of the operational risks. Lewis and Algaoud (2001) note that the Islamic Financial Service Board considers noncompliance as a very significant part of operational risks. This noncompliance arises from the failure of the institution to comply with the Islamic banking rules, and this failure often results in the cancellation of the transaction. The board states that fiduciary risks are risks that arise when the financial institution fails to carry out its activities based on the applicable standards. A failure to maintain the fiduciary responsibilities result in the deterioration of the institution's reputation, and the reputation damage causes a fund withdrawal plunging the institution into a liquidity crisis. It can also push the clients to halt requesting financial services from the institution and eventual trigger drop-in profitability.

Knežević (2013) observed that among the numerous financial risks inherent in the banking industry, there is a special place for operational risks. The uniqueness of operational risks in the banking sector comes from the fact that these risks follow banking transactions from the start to the end with high interconnectivity with other risks. The researcher noted that often it is hard to differentiate market risks with operational risks and these risks only come to be known several days or months after the transaction. The researcher cited the LIBOR fraud that was discovered in 2012 as an example of operational risks. It is arguably the biggest fraud case in the banking sector. The committee members who were tasked with the determination of LIBOR daily reported incorrect data on the interests offered as a way of presenting a healthy financial position of the institution. The fraud lasted for six years involving senior members of the management team. Consequently, Barclays bank was fined $\$ 450$ million, while the Swiss-based UBS fined $\$ 1.5$ billion, adds that because of the enormous significance of operational risks in the banking sector, BASEL I and II provided 
important incentives in the management of operational risks.

Savic (2012) proposes a change in the definition of operational risks to include moral hazards as an integral part of operational risks; moral hazards are the consequences of information asymmetry. Misihkin (2006) simplifies it by saying moral hazard happens when the lender (bank) is subject to actions that are immoral (undesirable) from the side of the lender; in other words, these activities reduces the chances of loan repayment. Knežević (2013) contended that there are numerous examples of how moral hazards can lead to operational risks. As an example, the 2008 financial crisis was as a result of moral hazards. Manager's greed largely caused the crisis for profits and bonuses, and this led to massive losses. The LIBOR scandal can also regard as a consequence of moral hazard. Concludes that moral hazards are not inherently limited to only internal processed but can also be derived from people or external events.

After the escalation of the 2008 financial crisis, it was discovered that one of the essential sources of turmoil among financial institutions was the lack of sufficient liquidity to cover systematic risks that are derived from huge credit losses. It was evident that the levels of capital from banks that were affected most was insufficient to absorb the potential losses and this indicated that ORM was inadequate in most financial institutions (BCBS, 2009). This is why all the implemented changes in BASEL III are seen as an attempt to enhance the internal processes of financial institutions and in effect leads to improvements in operational risk management.

In the modern banking industry, operational risks stand as one of the challenges affecting the industry, albeit it attracts little attention. Most banks are concerned with the risk arising from credit. ORM is focused on the quickly controllable and countable risk and their sources. The key question that bank managers should ask themselves is, how best they can handle operational risks in the future and how best they can recognize them early enough. Where enhancing the internal models of operational risk management remain a crucial task to bank managers.

\subsubsection{People Risk}

The management of employee's behaviour and human resources are regarded as major sources of the operational risks. Overworked employees and poorly trained may inadvertently expose errors that lead to operational risk in banks. Also, understanding of confidence, mandate, and strategies are significant for efficient operations. Furthermore, availability of employees, ability to replace them may influence bank's ability to continue with its activities and recover from interruptions. With this employee should be aware of such operational risks as well as learn them from their mistakes.

According to Knežević (2013), retail banks have more employees and transactions than large corporate banks. He notes that there is a higher possibility of unintentional errors because most the workers get tired due to the many operations daily. During the time of expansion, coupled with the growing number of workers, there is a high risk of insufficient training of the employees, and this eventually leads to an increase in accidental errors. As proposed by 
BASEL II, this kind of risk event is categorized as delivery, execution and process management, and are caused by human factors. Also, there is an inadequate level of control in many retail banks. Large transactions involve vast amounts, and this opens room for fraud and unintentional errors while meeting the professional obligations (National bank, 2006). Also, the high level of decentralization in the decision-making process that is highly correlated with moral hazards can lead to internal fraud and theft.

Also, Knežević (2013) pointed an example of retail banks in Serbia where financial records are not audited, and this makes it easy for some employees to forge them; this can be treated as a moral hazard. Similarly, Mabwe (2015) researched to investigate operational risk management with special emphasis being on people. Contends that by interviewing operational risk managers, operational risk consultants and junior bank operatives, it is possible to understand the concept of operational risk management and the role of people in operational risk. The study by Mabwe extends into an understanding of the three lines of defense theory in understanding operational risks in financial institutions, and correctly, identifies people as critical part of the defence.

\subsubsection{Internal Operations}

It is widely held that the most challenging driver of risk in financial institutions lies in the internal procedures and processes. Operational risk in the banking sector are inherent to the internal processes, and sometimes it can be difficult to differentiate the risk caused by people and those that are due to the failure of the internal processes. Knežević (2013) notes that failures and omissions in the bank's internal operations can be unintentional due to a minor misunderstanding of the process or intentional with the aim of gaining more profits by exposing the institution to higher risks. Overlapping of responsibilities with the bank can lead to a failure in the internal processes. When the employees are not set adequately and adequately, overlapping of duties can happen, and this often leads to omissions and inefficiency during work (Rahim et al., 2017). Other than the unintentional failures within the process, sometimes bank procedures can have loopholes that allow individuals to make personal gains or expose the bank to higher risks than what is expected. Researched noted that if the bank procedures do no cover all aspects of the internal process, there is a high chance of breaches of responsibility by the employees. Concludes that the biggest threat to internal processes emanates from moral hazards, though the failures are never identified in that manner.

\subsubsection{External Events}

Knežević (2013) contends that external events as a source of operational risk are beyond the control of the banks. Often, there is a higher possibility of customer forgeries and fraud. Banks operate in a working environment that is characterized by corruption, and it is no surprise some clients attempt to forge documentation on their financial results as well as providing false certification on properties, Embrechts et al. (2003). Also, Wu Yan (2008) notes that entrepreneur tendency to misuse the borrowed funds as a way of increasing personal fortune is directly dependent on the firms financing choices and it is high in firms that finance their projects using bank loans. As an example, Knežević (2013) notes that most 
of the business in Serbia finance their activities through bank loans and this is an important issue to risk management for financial institutions. However, these problems are not under the control of the banks.

\subsubsection{IT System Risks}

Different processes and systems support bank's operations. These include human resource management, market, insurance, liquidity risk management and credit systems and IT systems. All these require different components to operate. An example is a system that deals with credit risk management in a bank should require processes for the measurement, monitoring, identification and credit risk control. Poorly and complex designed systems may lead to a rise of operational risk in banks due to their unfit for purpose and malfunction. The range of problems is experienced when they fail namely fraud, processing errors and data security failures. Also, our reliance on information technology may lead to the major transforming of risk.

Kaspereit et al.. (2017) aimed to study the content of information on operational loss events occurring in European financial institutions, with competitors from the banking sector declared from the perspective of equity investors. The results showed that there were significant negative abnormal returns after the declaration of operational losses exceeding $€$ 50 million for each of the declared firms and their competitors.

Chernobai et al. (2008) contend that IT systems in banks are used to increase efficiency and effectiveness. They make operations faster, simplify labour and improve the flow of information and data. However, these systems sometimes fail, and typically it leads to losses that have significant implications for the organization for example of the Master Card Computer virus that involved a computer virus capturing client information for fraud. Another example is that of November 2010, where an extensive computer disruption in one of the Swedish bank affected the whole bank system including the ATMs and the branches. A study by McPhail (2013) identifies safely likely operational risk problems in the banking industry, among them the failure of time-sensitive payment needs and the dislocation of payment systems.

The implementation of IT in banks can lead to challenges in the workflow, policies or procedures and this ultimately lead to risks. In another study, Fheili (2011) notes that the operational risks in the banking sector cannot be considered independently and when there is a connection with processes, people or other related risks. Indicates that IT system problems are majorly caused by Cyber- attacks, viruses and other failures and this result in significant issues that affect the whole system. Because of this, technology and system risk can be classified as the risk of loss due to imperfect systems in banks. Moreover, such imperfection includes inappropriate data processing, lack of system capacity, and poor quality of data or using low technology. Thus, Culbertson (2004) advice that using an effecting IT system together with- IT security leads to successful management of IT-related risks in an organization. 


\subsection{Risk Management}

Risk management is a primary component of any successful finance and investment. According to Aebi et al. (2012), the need for the adoption of effective risk management in financial institutions together with strict conformity to good corporate governance are crucial to the success of any banking institution. When financial institutions adopt sophisticated risk management practices and create the possibility of having an effective and sound management strategy, Kim and Vonortas (2014) note that it increases the chances of their long-term survival. It should be noted that the process of risk management should be fully understood by the board of directors as well as all other employees for any meaningful change to be realized.

According to Karim and Zahisyam (2017) aimed to examine the factors affecting risk and performance in the banking institution and identify critical factors influencing risk in bank operation in Malaysia. Hence, the results suggested several implications. First, considering that credit risk in OCBC Bank remains high and this needs attention to risk management in this bank especially in the factors that have a significant impact on bank credit risk. Second, corporate governance in the bank also affects the performance of the bank. The board should be higher and adequately disclose all the essential information when reporting. It will help investors to evaluate and interesting to invest in this bank.

To ensure that the process of risk management in financial institutions is implemented accurately there should be an internal Chief Risk Officer. The purpose of CRO is to ensure all the risk are strategically assessed and in-line with the corporate strategy. Overall, the work of the CRO is to provide there is a useful internal control system that is implemented to manage the risk from within efficiently. However, obstacles such as inadequate risk managers, poor attitude towards risk management and inappropriate risk management need to be understood as active risk management (Carter and Chinyio, 2012).

According to Basel II (2006) risk management is defined as identification, prioritization and assessment of risks followed by economic application of available resources and coordination to minimize, control and monitor impact and probability of unfortunate events.

Risk management is all about making right decisions that contribute overall achievements of a firm's objectives by applying them both to functional areas and individual activity. Therefore, ensures mission, vision, and goals are met due diligence, accountability, innovation and responsible risk-taking. Safety management subsumes all activities relating to the organization, planning, supervision of work activities and administration.

Additionally, risk management through integrated risk management is vital as it covers various types of risks namely financial risks, liquidity risk, operational risk and market risks among others.

Various tools and techniques are used in risk management by banks and other financial institutions these includes:

1- Risk avoidance - Organizations such as banks can decide not to perform the activities that 
could result to risk. This is seen as the answer to all risks despite the technique leading to losing out important potential gains. An example was failing to get into a risky business yield low profits to an organization. Since operational, liquidity and outsourcing risk are common in banks, they always run away from these activities (Cagno, E et al. 2007).

2- Risk reduction - This is also known as optimization and involves reducing likelihood or severity of loss from occurring in an organization. Most of them understand that risks can be negative or positive that finding the balance between existing negative risks and operation benefits and effort applied then risks are optimized. With this, they can achieve levels of operational and residual risks which are tolerable. Establishment of modern software in banks have ensured activities are not jeopardized. This has seen outsourcing risk, credit risk, fraud, operational risks minimized (Bolvin, C. 2007).

3- Risk sharing - According to Datta, K. (2007, January), many organizations have opted to share their burden of risks as a way to manage, reap benefits and reduce a risk. The risk is transferred to a third party through outsourcing and insurance. Many risk practitioners ensure their company purchases insurance contract to retain legal responsibility and ensure compensation by insurance companies.

4- Risk retention - This is a strategy where banks accept benefits of gain or losses. Despite this not all risks are avoided such as cyber-attacks, operational risks, fraud and IT failure hence those that are transferable are retained as default. These losses are known to be catastrophic and large hence they should be managed. These risks include operational risks, It failure, fraud, cyber-attacks among others thus good risk management plan is needed.

\subsubsection{Operational Risk Management (ORM)}

Considering the basic steps involved in risk management, operational risk management dwells on the issue that is not financial but can lead to a financial loss. Operational risk in a bank can happen at any level. Given that external and internal injuries usually are closely linked to the individual institution, Apatachioae (2014) operational data in banks should be quite detailed to include a clear and comprehensive classification of the all the internal weaknesses when adoption changes.

Sharifi et al. (2016), studied the relationship between operational risk management, bank size, and ownership in 61 Indian banks during the period from 2010 to 2013 and found out that there is no significant relationship between ownership whether public, private or foreign and excess capital held by banks for managing operational risk.

Wiley (2013) contend that after the end of some rogue businesses events in the 90s, the BCBS came up with a framework for managing and providing regulatory services for operational risks in financial institutions. Andersen et al. (2012) note that the primary cause of historical financial crisis among financial institutions is the gross violation of operational risk management procedures, and mostly, it is due to lack of adequate attention to its processes and functions. Research by Cagan (2009) reveals that the level of operational risk losses during the 2008 financial crisis was four times larger than the previous year. He notes that the risk never changed in frequent but increased in severity and this is the reason why the 
financial impact in 2008 was more massive than in 2007.

Also, Jongh et al., (2013) contend that the appearance of modern and advanced IT systems has increased the attention of operational risk management in financial institutions. Accordingly, Apatachioae (2014) stresses that the imperfection of the IT and data architecture to support the process of risk management is one of the most excellent lesson learned by operational risk managers from the financial crisis of 2008. However, after the crisis, operational risk management still faces numerous challenges with many uncertainties and decision makers in the financial institutions are still faced with the biggest problem of managing the risks associated with the failure of banking institutions. Also, McLaughlin (2013) notes that a somewhat new aspect that appeared came up in operational risk management after the 2008 financial crisis is the changing behaviors of investors towards risks.

\subsubsection{Operational Risk Reporting}

Risk reporting plays a significant role in risk management. According to the Financial Stability Board (2014), risk reporting is a critical segment of disclosure in the financial sector. After the great financial crisis of 2008, risk reporting risk disclosure turned out to be the most effective tools that could be used to avoid future bank crises. Barakat and Hussainey (2013) discuss the impact of bad corporate governance, supervisions, and regulations on the quality of risk reporting within the framework of operational risks. For financial institutions to better prepare themselves for a possible financial crisis, the improvement of the quality of risk management and the embedment of risk governance to the CEO who reports directly to the board are needed. Further, Howell (2014) adds that effective risk reporting is achieved through close collaboration between the senior management team and the board, where the role of the management is not only limited to the provisions of Facts but also an explanation of key performance indicators. Also, Howell (2014) notes that the shift from manual reporting to the use of digital technologies provides sufficient time for the analysis of risks and this ultimately increases the quality of risk reporting.

According to Helbok and Wagner (2006). The present paper tries to find the truth about operational risk making known practices in the 1998 to 2001 period. Agreeing with working regularly with arguments based on corporate finance theory, evidence points to/shows that banks with a lower equity/assets ratio and profitability ratio give greater importance to evaluation and management of operational risks whereas those with higher ratios choose a more moderate disclosure stance.

\subsubsection{The Three Lines of Defense (3LoD)}

Luburić (2017), aimed to strengthen the model of three lines defense for making operational risk management more efficient. Therefore, the study showed that the integration of quality management principles and risk management principles are significantly strengthened the three lines of defense and contributed to the full effectiveness and efficiency of the risk management process. Doughty (2011) contends that strategic implementation of the three lines of defense is the number one principle of the operational risk governance framework for 


\section{Ml Macrothink}

Business and Economic Research

ISSN 2162-4860

2018, Vol. 8, No. 2

financial institutions. Currently, the three lines of defense are the standard model by which financial institutions use to manage uncertainty and prevent risks. Doughty notes that the first line is frontline personnel, whose main task is to understand the responsibilities and ensure they are performed accurately and fully daily. Additionally, the first line of defense requires the employees to apply the internal control in treating the risks associated with individual tasks. Other than the frontline employees, a bank needs to have the risk management committee tasked with monitoring the risks within the organization.

The second line of defense is made of supervision functions that include risk control and compliance. The duty of this line personnel includes reviewing risk reporting, participating in risk reporting committees and validating risk compliance. Doughty (2011) notes that it is critical to note that questions related to risk appetite, culture, budget, and monitoring are often directed to the second line of defense.

The last line of defense consists of internal auditors who objectively and independently assume the role of the consultant. They assist the organizations to attain their goals by introducing systematic approaches to effective risk management and procedures. Doughty (2011) notes that the third line of defense involves a higher level of interdependency compared to the first and second line.

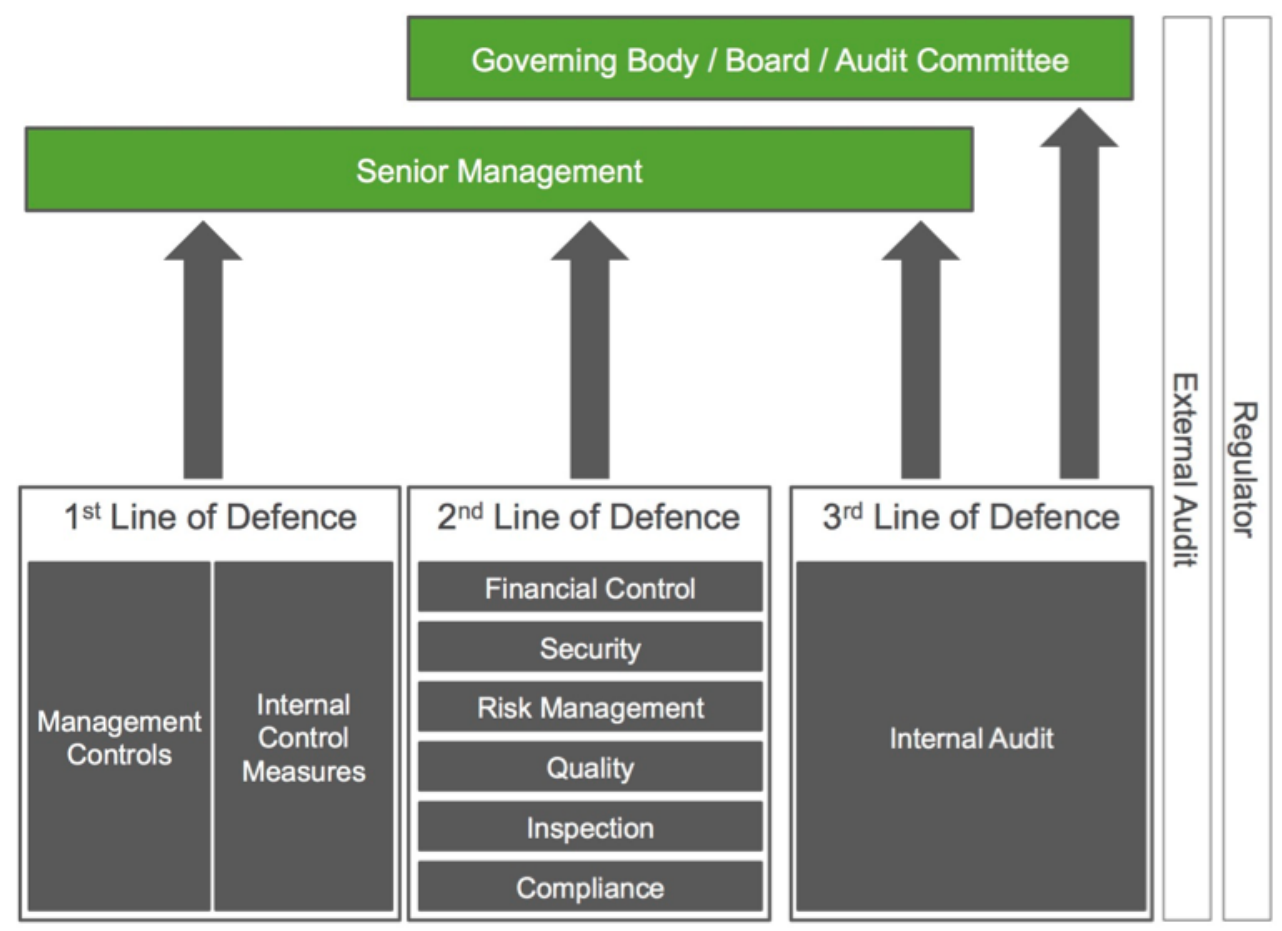

Figure 1. Anderson and Eubanks (2015)

It has been confirmed that organizations that lack well stabled three lines of defense are in great danger of having challenges such as the existence of gaps in risk coverage, less control, high costs and ineffective risk control measures and procedures. However, Doughty (2011) notes that there is limited evidence on the challenges and drawbacks that an organization is likely to experience an organization is likely to face on using the three lines of defense model. 


\subsubsection{Stress Test}

Stress testing was an active instrument in the supervision of bank capital during the financial crisis. Stress tests can improve supervision of bank capital by giving a more forward-looking and adaptable process for testing-related risks that might not be fully taken by risk-based capital standards. The level and quality of capital among large banking organizations have increased especially since the introduction of stress tests during the financial crisis.

Bologna \& Segura (2017) described how supervisory stress tests can addition the risk-based capital structure of Basel III and how this could be systematized with a stress test buffer. We then argue that to secure sure of clearness of thinking with the macroprudential goals of Basel III, the extreme harshness of supervisory stress tests should be procyclical.

As concerns for bank capitalization, particular among larger banks increased during the great financial crisis, the stress test was used as a simulation or analysis tool for the determination of the ability of the banks or institutions to handle a possible financial crisis. The stress test is defined as a category that represents that assessment of the institution's financial stability when faced with severe risk events that might affect its performance. Negrila (2010), the stress test was suggested as one of the best methods that could be used to measure the preparedness of the financial institutions towards risks and crisis at the time of economic development. It is crucial to note that after the introduction of the stress test, Furlong (2011) found there were significant changes to the level and quality of capital in financial institutions. Empirical studies conclude that stress test is significant and a must have control tool for monitoring the capital and financial stability of the banks and other financial institutions.

Bayazitova \& Shivdasani (2011) studied the government equity infusions into banks under the Capital Purchase Program (CPP) of the Troubled Asset Relief Program (TARP). Strong banks opted out of CPP, and equity infusions were provided to banks that posed a systemic risk and faced high financial distress costs but had strong asset quality.

The study indicated the subsequent stress tests conducted for the major banks had significant certification effects.

\subsubsection{Banking Mechanisms to Manage Operational Risk}

According to a theoretical framework for the operational risk in banks have come up with a mechanism to mitigate and grip from operational risks. These include;

I. All bank units shall conduct exercises on self-assessment of the particular operational risks that inherent in its activities. This includes their assessment and identification concerning their frequency of materiality and occurrence and shall report all identified vents to Operational and Compliance Risk Management Offices. This will create mechanisms to ensure banks management are fostered.

II. All key risk indicators will be developed by banks where appropriate. This acts as an early warning to banks on increase risk, potential losses and threats. Effective tracking and monitoring of these indicators help the bank to identify operational changing risks upon the occurrence thus responding to them promptly. 
III. Insurance policies are embraced by banks to confront losses that may occur due to third-party event claims resulting to omissions, errors, natural disasters and employee fraud.

IV. Business continuity and disaster recovery plans will be considered in monetary scenarios at which bank can be commensurate, vulnerable to complexity and size of its operations. These plans happen periodically and should frequently be tested and reviewed.

V. Adequate training is being enhanced by banks to ensure adequate performance by employees, appropriate expertise to staff and career advancement should be put in place. This ensures operational risk instances are reduced.

VI. During the new product approval development by banks the operational risk regarding each new activity, product, system, and process will be assessed, identified and mitigated controls shall be established.

\subsubsection{Operational Risk Identification and Measurement}

According to Padganech (2010), the measurement of operational risks in most banks is at early stages with only a few of them having formal measuring procedures in place. The existing methodologies in operational risk management are experimental and straightforward, and a few financial institutions have made considerable progress in the development of more advanced techniques that could be used in the allocation of capital for dealing with operational risks. The following approaches are used in the banking sector to identify operational risks. Additionally, Epetimehin (2013) showed that most accounting firms have an awareness of operational risk as a different risk class, and have started to include in their annual reports notes on risks or lessons learned from bank risks. Many financial institutions observe the operational performance indicators, analyze the experiences of loss and control the audit and regulatory classifications, but a few measures and report their risks on a regular basis, and there is still no clear mathematical or statistical relationship between individual risk factors and the size of operating losses. However, Basel Accord outlined three methods for computing the minimum capital charge for operational risk in a series of rising sophistication and risk sensitivity.

\subsubsection{Top-down and Bottom-up Approaches}

Allen et al. (2016) this study aimed to analyze the range effectiveness of portfolio diversification strategies, concentrating on down-side risk metrics, as a portfolio diversification strategy in a European market context. Thus, the results suggested that none of the more sophisticated optimization strategies appear to dominate naive diversification.

According to Padganech, (2010) the measurement of operational risk in banks is still in a developing art form. He notes that the top-down and the bottom-up approaches were developed as a more sophisticated approach to the measuring and management of operational risks in financial institutions. The top-down approach that estimates the operational risks based on the firm-wide data as a model that is easier and faster to apply but it is insensitive to 
the accrual or implementation. On the other hand, however, the bottom-up approach provides an efficient structural model that is more useful in the understanding of the cause of operational risk in financial institutions. The model involves mapping of workflows that are used in the identification of potential failures and risks.

\subsubsection{The Balanced Scorecard Approach}

The approach is widely used in strategic management and was developed by Kaplan, of the Harvard Business School, and Norton. The system was named as the balanced scorecard, after recognizing the weaknesses and vagueness of previous approaches; the approach provides a clear outline of what institutions should do for them to balance their financial perspectives. Kaplan and Norton describe the innovation of this approach as the retention of traditional financial measures. However, these financial measures are inadequate in telling and guiding the journey that companies in the information age should take in creating future value for customers. The approach is a management system that allows banks to clarify their vision and strategy and turn them into actions. The balanced scorecard provides feedback around not only just internal but also external outcomes to continually improve the outcome. When fully utilized, it can transform the bank's strategic planning from a paper exercise to a nerve center for the success of the organization.

According to Mehralian et al. (2017). The motivation behind this paper is to look at the connection between the performance of total quality management (TQM) and organizational performance, using the balanced scorecard (BSC) approach, the results supported the research model and showed that TQM performance could positively and significantly impact the BSC and its four points of view.

\subsubsection{Operational Risk Measurement Procedures}

According to Epetimehin (2013), this paper showed that most accounting firms have an awareness of operational risk as a different risk class, and have started to include in their annual reports notes on risks or lessons learned from bank risks. Many financial institutions observe the operational performance indicators, analyze the experiences of loss and control the audit and regulatory classifications, but a few measures and report their risks on a regular basis, and there is still no clear statistical relationship or mathematical between individual risk factors and the size of operating losses. However, Basel Accord outlined three methods for computing the minimum capital charge for operational risk in a series of rising sophistication and risk sensitivity.

These are the necessary indicator approach (BIA), the standardized approach (TSA) and advanced measurement approach (AMA). Typically, a bank is allowed to implement the BIA or TSA for some parts of its operations and AMA for others.

Operational risk measurement can be targeted as the top down or the bottom up approach depending on the method of computing the risk charge. In the top-down approach, banks use financial data from financial statements (such as balance sheet and profit and loss statement) and utilize BIA, and TSA approaches. Whereas the bottom-up approach utilizes the estimates from internal operational risk assessments. Thus, bottom-up method corresponds with the 
AMA. We briefly discuss these three procedures in the following paragraphs (Sharifi, Sirus, et al.2016).

\subsection{Basic Indicator Approach (BIA)}

The BIA is the simplest approach to calculating operational risk capital charges. In this approach, banks use "gross income (GI)" as a single proxy for their overall operational risk exposure. According to this approach, the minimum capital requirement is a percentage (15 percent) of the average positive gross income (GI) of the preceding three years. Years with negative GI indicator are excluded:

$$
\mathrm{K} \mathrm{BIA}=[\Sigma(\mathrm{GI} 1 \ldots \mathrm{n} \times \alpha)] / \mathrm{n}
$$

Where $\mathrm{K}$ BIA = The capital charge under the Basic Indicator Approach.GI $=$ annual gross income, where positive, over the previous three years. $\mathrm{N}=$ number of the previous three years for which gross income is positive. $\alpha=15 \%$, which is set by the Committee, relating the industry-wide level of required capital to the industry-wide level of the indicator.

Gross income is defined as net interest income plus net non-interest income. It is intended that this measure should:

(i) be gross of any provisions (e.g., for unpaid interest):

(ii) be gross of operating expenses, including fees paid to outsource service providers,

(iii) exclude realized profits/Losses from the sale of securities in the banking book,

(iv) exclude extraordinary or irregular items as well as income derived from insurance.

\subsection{Standardized Approach (SA)}

The TSA is the advanced method of measurement of operational risk in comparison with BIA. Under this approach, bank's activities are classified into different standardized business lines. Each business line has a broad financial indicator which acts as a proxy for the amount of operational risk for each of those business lines. Operational risk capital charged for each business line is computed by multiplying its financial indicator by "beta" factor. Beta is a proxy for the relationship between operational loss experience and the financial indicator in a specific business line. GI is a proxy for operational risk exposure in each business line. The eight business lines with their recognized $\beta$-values by risk managers are listed in Table 1 . In this approach, total regulatory capital is calculated as the three-year average of an aggregate of the capital charge across each of the business lines in each year (Basel Committee, 2006).

$$
\mathrm{KTSA}=\{\Sigma \text { years } 1-3 \max [\Sigma(\mathrm{GI} 1-8 \times \beta 1-8), 0]\} / 3
$$

KTSA=The capital charge under the Standardized Approach.GI1-8 = Annual gross income in a given year, as defined above in the Basic Indicator Approach, for each of the eight business Lines. $\beta 1-8=$ A fixed percentage, set by the Committee, relating the level of required capital to the level of the gross income for each of the eight business lines, the values of the betas are detailed below. 
Table 1.

\begin{tabular}{|l|l|}
\hline Business Lines & Beta Factors \\
\hline Corporate finance & $18 \%$ \\
\hline Trading and sales & $18 \%$ \\
\hline Retail banking & $12 \%$ \\
\hline Commercial Banking & $15 \%$ \\
\hline Payment and settlement & $18 \%$ \\
\hline Agency services & $15 \%$ \\
\hline Asset management & $12 \%$ \\
\hline Retail brokerage & $12 \%$ \\
\hline
\end{tabular}

\subsection{Advanced Measurement Approach (AMA).}

AMA seems to be the most suitable approach in the calculation of operational risks. It is better suited than other methods because it enables financial institutions to have flexibility in coming up with the most suitable risk measurement system that best works for it. Besides, BASEL committee recommends the use of AMA as one of the best approaches to operational risk management. Useful AMA requires necessary internal and external data on loss events from similar institutions. A detailed assessment of the control mechanism, environment, and measurement systems are all needed in useful AMA. Overall, the requirements can be stringent when examining what should be included in both internal and external data on losses. When considering risk mitigation, the bank can transfer risks using products such as insurance, in which the allowed amount is $20 \%$ of the total operational risk exposure that can be supported by the available data. Testing and verification are also crucial in AMA. There has to be a policy that dictates the way the collected data is delivered, sored and its accessibility for the maintenance of data integrity.

Chung et al. (2017) shed light on Quantification of operational risk has led to the significant importance that related to regulation in the financial industry. Basel Agreement II and III for banks and Solvency II for insurers require insurance companies and banks to set apart and distribute capital for operational risk. It is almost incapable of being done to get a true number guess of some such a risk measure if a straightforward Monte Carlo approach is used. Number-based results show that the proposed method is efficient and robust.

\section{Conclusion}

This study aimed to presents the framework of operational risks management and link with Basel committee. Regarding the increasing significance of operational risks management, this framework tries to identify the fundamental and underlying principles of operational risks and how financial institutions can manage these risks. Also, we reviewed the previous studies and linked with theoretical framework of operational risk management

For better management of operational risks in banks, there is the need to comply with both the national and international regulations and procedures. The period during and after 2008 was important in providing insight on how important operational risk management is vital to financial institutions and how best these risks can be managed. 


\section{Macrothink}

Business and Economic Research ISSN 2162-4860 2018, Vol. 8, No. 2

Future research can annually testify risk management, to monitor the development of banks and study the most critical bank problems, and make recommendations for boards of directors in banks in this regard. Also, we recommend more empirical research to analyze the influence of following the global regulation in regards to decreasing the operational risk in financial institutions. Also, more theoretical and practical studies may conduct in developing countries which have a weak financial system or unstable in the economic and political regime.

Banks management should disclose the overall framework (strategy) for operational risk management in a manner that allows investors and stakeholders to identify the bank's efficiency in identifying, evaluating, controlling, mitigating and controlling operational risks. Banks highly recommended assessing of operational risk so that it is consistent with bank's current operations and business strategies and policies. Senior management can ensure that the bank's operational risk management framework is subject to efficient and comprehensive review by internal auditor by independent, trained, experienced and knowledgeable staff. Senior management of banks should encourage the corporations between internal audit and group risk management department to ensure that branches are fully aware of the procedures and regulations related to the internal control system and operational risk management.

\section{References}

Aebi, V., Sabato, G., \& Schmid, M. (2012). Risk management, corporate governance, and bank performance in the financial crisis. Journal of Banking \& Finance, 36(12), 3213-3226. https://doi.org/10.1016/j.jbankfin.2011.10.020

Allen, D. E., McAleer, M., Powell, R. J., \& Singh, A. K. (2016). Down-Side Risk Metrics as Portfolio Diversification Strategies across the Global Financial Crisis. Journal of Risk and Financial Management, 9(2), 6. https://doi.org/10.3390/jrfm9020006

Andersen, L. B., Häger, D., Maberg, S., Næss, M. B., \& Tungland, M. (2012). The financial crisis in an operational risk management context-A review of causes and influencing factors. Reliability Engineering \& System Safety, 105, 3-12. https://doi.org/10.1016/j.ress.2011.09.005

Apătăchioae, A. (2014). New challenges in the management of banking risks. Procedia Economics and Finance, 15, 1364-1373. https://doi.org/10.1016/S2212-5671(14)00600-5

Barakat, A., \& Hussainey, K. (2013). Bank governance, regulation, supervision, and risk reporting: Evidence from operational risk disclosures in European banks. International Review of Financial Analysis, 30, 254-273. https://doi.org/10.1016/j.irfa.2013.07.002.

Basel Committee on Banking Supervision (2006). International Convergence on Capital Measurement and Capital Standards (A revised framework, comprehensive version). Retrieved from http://www.bis.org/publ/bcbs128.pdf .

Basel Committee on Banking Supervision (2009). Strengthening the resilience of the banking sector. Retrieved from www.bis.org/publ/bcbs164.pdf

Basel Committee on Banking Supervision. (2004). Range of Practice in Banks' Internal Ratings Systems. 
Bayazitova, D., \& Shivdasani, A. (2011). Assessing tarp. The Review of Financial Studies, 25(2), 377-407. https://doi.org/10.1093/rfs/hhr121.

Bitar, M., Naceur, M. S. B., Ayadi, R., \& Walker, T. (2017). Basel Compliance and Financial Stability: Evidence from Islamic Banks. International Monetary Fund. https://doi.org/10.5089/9781484309216.001

Bogodistov, Y., \& Wohlgemuth, V. (2017). Enterprise risk management: a capability-based perspective. The Journal of Risk Finance, 18(3), 234-251.

https://doi.org/10.1108/JRF-10-2016-0131.

Bologna, P., \& Segura, A. (2017). Integrating stress tests within the Basel III capital framework: a macroprudentially coherent approach. Journal of Financial Regulation, 3(2), 159-186. https://doi.org/10.1093/jfr/fjx004.

Bolvin, C., Farret, R., \& Salvi, O. (2007, September). Convergence towards integrated risk management: results from the European SHAPE-RISK project and other initiatives. In 1. International Conference on risk analysis and crisis response (p. NC).

Cagan, P. (2009). Managing operational risk through the credit crisis. The Journal of Compliance, Risk \& Opportunity, 3(2), 19-26.

Cagno, E., Caron, F., \& Mancini, M. (2007). A multi-dimensional analysis of major risks in complex projects. Risk Management, 9(1), 1-18.

https://doi.org/10.1057/palgrave.rm.8250014.

Carter, A., \& Chinyio, E. (2012). Effectiveness of risk management: barriers and solutions. International Journal of Project Organisation and Management 5, 4(4), 368-378. https://doi.org/10.1504/IJPOM.2012.050330.

Chernobai, A. S., Rachev, S. T., \& Fabozzi, F. J. (2008). Operational risk: a guide to Basel II capital requirements, models, and analysis (Vol. 180). John Wiley \& Sons.

Chung, M. T., Hsieh, M. H., \& Chi, Y. P. (2017). Computation of Operational Risk for Financial Institutions. Journal for Economic Forecasting, (3), 77-87.

Cornia, A., Dressel, K., \& Pfeil, P. (2016). Risk cultures and dominant approaches towards disasters in seven European countries. Journal of Risk Research, 19(3), 288-304. https://doi.org/10.1080/13669877.2014.961520

Culbertson, D. (2004). IT risk: A new challenge for community bank, Bank News. http://www.diva-portal.org/smash/record.jsf?pid=diva2:824269

Cummins, J. D., Lewis, C. M., \& Wei, R. (2006). The market value impact of operational loss events for US banks and insurers. Journal of Banking \& Finance, 30(10), 2605-2634. https://doi.org/10.1016/j.jbankfin.2005.09.015

Datta, K. (2007, January). The application of NASA risk management to the SOFIA program. In Reliability and Maintainability Symposium, 2007. RAMS'07. Annual (pp. 410-413). IEEE. https://doi.org/10.1109/RAMS.2007.328077 
Di Renzo, B., Hillairet, M., Picard, M., Rifaut, A., Bernard, C., Hagen, D., ... Reinard, D. (2007). Operational risk management in financial institutions: Process assessment in concordance with Basel II. Software Process: Improvement and Practice, 12(4), 321-330. https://doi.org/10.1002/spip.322.

Doughty, K. (2011). Guest Editorial: The Three Lines of Defence Related to Risk Governance. ISACA Journal, 5, 6.

Embrechts, P., Furrer, H., \& Kaufmann, R. (2003). Quantifying regulatory capital for operational risk. Derivatives Use, Trading and Regulation, 9(3), 217-233.

http://doi.org/10.1.1.134.5420 \&rep=rep1\&type=pdf.

Epetimehin, F., \& Ekundayo, O. (2013). Risk pricing and profit maximization of insurance companies. Journal of Research in National Development, 10(3), 301-305.

Esposito, S., Stojadinović, B., Babič, A., Dolšek, M., Iqbal, S., Selva, J., \& Giardini, D. (2017). Engineering risk-based methodology for stress testing of critical non-nuclear Infrastructures (STREST Project). In 16th World Conference on Earthquake Engineering, Santiago.

Fheili, M. I. (2011). Information technology at the forefront of operational risk: banks are at a greater risk. The Journal of Operational Risk, 6(2), 47.

https://doi.org/10.21314/JOP.2011.092

Frederic, M. S. (2006). Monetarna ekonomija, bankarstvo i finansijska tržišta. Data status, Beograd. http://www.datastatus.rs/

Furlong, F. (2011). Stress testing and bank capital supervision. FRBSF Economic Letter, 20, 27. https://www.frbsf.org/economic-research/files/el2011-20.pdf

Ganegoda, A., \& Evans, J. (2014). A framework to manage the measurable, immeasurable and the unidentifiable financial risk. Australian Journal of Management, 39(1), 5-34. https://doi.org/10.1177/0312896212461033

Hamberg, M. (2000). Risk, uncertainty \& profitability: An accounting-based study of industrial firms' financial performance (Doctoral dissertation, Acta Universitatis Upsaliensis). http://www.diva-portal.org/smash/record.jsf?pid=diva2:160733

Helbok, G., \& Wagner, C. (2006). Determinants of operational risk reporting in the banking industry. http://dx.doi.org/10.2139/ssrn.425720

Hess, C. (2011). The impact of the financial crisis on operational risk in the financial services industry: Empirical evidence. The Journal of Operational Risk, 6(1), 23.

https://doi.org/10.21314/JOP.2011.087

Howell, J. (2014). Board reporting trends and best practices in the Digital Age. Financial Executive, 30(4), 32-37.

Hussain, M. S., \& Shafi, M. OPERATIONAL RISK IN BANKS: A REVIEW. 
Ibrahimovic, S., \& Franke, U. (2017). A probabilistic approach to IT risk management in the Basel regulatory framework: A case study. Journal of Financial Regulation and Compliance, 25(2), 176-195. https://doi.org/10.1108/JFRC-06-2016-0050

De Jongh, E., De Jongh, D., De Jongh, R., \& Van Vuuren, G. (2013). A review of operational risk in banks and its role in the financial crisis. South African Journal of Economic and Management Sciences, 16(4), 364-382. https://doi.org/10.4102/sajems.v16i4.440

Kaplan, S., \& Garrick, B. J. (2006). On the quantitative definition of risk. Risk analysis, 1(1), 11-27. https://doi.org/10.1111/j.1539-6924.1981.tb01350.x

Karim, A., \& Zahisyam, M. (2017). Financial Risk and Performance: Empirical Evidence from OCBC Bank (Malaysia) Berhad. https://mpra.ub.uni-muenchen.de/id/eprint/78348

Kaspereit, T., Lopatta, K., Pakhchanyan, S., \& Prokop, J. (2017). Systemic operational risk: spillover effects of large operational losses in the European banking industry. The Journal of Risk Finance, 18(3). https://doi.org/10.1108/JRF-11-2016-0141

Knežević, M. (2013). Operational Risk-Challenges for Banking Industry. Economic analysis, 46(1-2), 40-52. Retrieved from http://ebooks.ien.bg.ac.rs/367/1/2013_1_2_4.pdf

Lewis, M. K., \& Algaoud, L. M. (2001). Islamic banking. Books.

https://doi.org/10.4337/9781843762959

Luburić, R. (2017). Strengthening the Three Lines of Defence in Terms of More Efficient Operational Risk Management in Central Banks. Journal of Central Banking Theory and Practice, 6(1), 29-53.https://doi.org/10.1515/jcbtp-2017-0003

Mabwe, K. (2015). Investigating the significance of people risk in the context of operational risk management in UK banks (Doctoral dissertation, Glasgow Caledonian University). http://ethos.bl.uk/OrderDetails.do?uin=uk.bl.ethos.687412

Massingham, P. (2010). Knowledge risk management: a framework. Journal of Knowledge Management, 14(3), 464-485. https://doi.org/10.1108/13673271011050166

McLaughlin, J. (2013). Operational Risk Management Is Critical to Bank Success, The RMA Journal, pp.56-59.

McPhail, K. (2003). Managing operational risk in payment, clearing, and settlement systems. Bank of Canada. Working Paper 2003-2. http://sbisrvntweb.uqac.ca/archivage/17521118.pdf

Mehralian, G., Nazari, J. A., Nazari, J. A., Nooriparto, G., \& Rasekh, H. R. (2017). TQM and organizational performance using the balanced scorecard approach. International Journal of Productivity and Performance Management, 66(1), 111-125.

https://doi.org/10.1108/IJPPM-08-2015-0114.

Nationalbank, Ö. (2006). Guidelines on Operational risk management. Oesterr. Nationalbank (OeNB).

Negrilă, A. (2010). The Role of Stress-test Scenarios in Risk Management Activities and in 
the Avoidance of a New Crisis. Theoretical \& Applied Economics, 17(2).

Nobanee, H., \& Ellili, N. (2017). Does Operational Risk Disclosure Quality Increase Operating Cash Flow of UAE Islamic and Conventional Bank.

http://dx.doi.org/10.2139/ssrn.2971479

Nystrom, K., \& Skoglund, J. (2002). Quantitative operational risk management. Group Financial Risk Control Swedbank. http://www.each.usp.br/rvicente/risco/nystrom.pdf

Parfenova, A., \& Karlsson, L. (2016). The effects of regulations on risk management within the Swedish Banking Sector.

Rahim, N. F. A., Jaafar, A. R., Syamsuddin, J., \& Sarkawi, M. N. (2017). Internal Control System and Hazard Identification of Operational Risk in Malaysian Conventional Banking. Int. J Sup. Chain. Mgt., 6(2), 215.

Sabato, G. (2010). Financial crisis: where did risk management fail? International review of applied financial issues and economics, 2(2), 315.

https://www.ceeol.com/search/article-detail?id=199317

Savić, A. (2012). Operativni rizici u bankama.

http://zandrejevic.rs/category/izdanja/?lang=cir

Schwartz-Gârliste, M. A. (2013). The Operational Risk Management in Banking-Evolution of Concepts and Principles, Basel II Challenges. Revista de Management Comparat International, 14(1), 165-174.

Sharifi, S., Haldar, A., Haldar, A., Rao, S. N., \& Rao, S. N. (2016). Relationship between operational risk management, size, and ownership of Indian banks. Managerial Finance, 42(10), 930-942. https://doi.org/10.1108/MF-05-2015-0145.

Vasavada, G., Kumar, S., Rao, S. U., \& Pai, S. (2005). General Bank Management. Mumbai: Indian Institute of Banking and Finance.

Wiley, J. (2013). Operational Risk Management. John Wiley and Sons.

Wu, Y. (2008). Capital Structure and Moral Hazard within Entrepreneurial Firms. citeseerx. ist. psu. edu/viewdoc/summary.

https://pdfs.semanticscholar.org/19c9/ec81ecc866aaf2028321af87a25b22962c09.pdf

\section{Copyright Disclaimer}

Copyright for this article is retained by the author(s), with first publication rights granted to the journal.

This is an open-access article distributed under the terms and conditions of the Creative Commons Attribution license (http://creativecommons.org/licenses/by/3.0/). 